\title{
O EXERCÍCIO DA CIDADANIA FISCAL
}

\section{THE PRACTICE OF FISCAL CITIZENSHIP}

\author{
Ana Maria da Costa Porto ${ }^{1}$ \\ Antônio de Moura Borges ${ }^{2}$
}

\section{RESUMO}

O cidadão não tem tido conhecimento adequado dos seus direitos e obrigações tributárias, faltando-lhe consciência do exercício da cidadania fiscal. O presente artigo traz uma análise sobre a importância de o cidadão ser informado a respeito dos tributos embutidos quando da aquisição de mercadorias e na prestação de serviços, bem como da forma como são realizados os gastos públicos, nascendo nele cidadania ativa e participativa, com o propósito de se atingir a cidadania fiscal.

Palavras-chave: Cidadania; Consciência Fiscal; Cidadania Fiscal; Tributos.

\begin{abstract}
The citizen is not always aware of his tax rights and obligations, lacking awareness of the exercise of fiscal and tax citizenship. This article presents an analysis of the importance of the citizen to be informed about the embedded taxes when purchasing goods and providing services, as well as the way tax expenditures are made, so that he acquires an active and participatory citizenship for the purpose of achieving fiscal citizenship.
\end{abstract}

Keywords: Citizenship; Tax Awareness; Fiscal Citizenship; Taxes.

\footnotetext{
${ }^{1}$ Mestranda em Direito pela Universidade Católica de Brasília - Distrito Federal, (Brasil). Advogada. Especialista em Direito Administrativo e Processo Administrativo pela Universidade Cândido Mendes. Professora no Curso de Direito. Advogada. E-mail: ana.costaporto@gmail.com

${ }^{2}$ Doutor em Direito pela Universidade de São Paulo - USP, São Paulo, (Brasil). Mestre em Direito pela Southern Methodist University - SMU (EUA). Professor na Universidade Católica de Brasília - UCB e na Universidade de Brasília - UnB. E-mail: amouraborges@ uol.com.br
} 


\section{INTRODUÇÃ̃}

O reconhecimento, pelo cidadão, dos seus deveres e direitos em matéria tributária se reveste de grande importância nos dias de hoje, dada a forte pressão fiscal, consequência principalmente do amplo papel atribuído ao Estado como forma de organização da sociedade e de promoção do bem-estar social. Tem-se frequentemente afirmado que falta-lhe consciência do exercício da cidadania fiscal.

São dois os grandes pressupostos necessários para o pleno desenvolvimento da noção de cidadania fiscal: sistema tributário considerado justo e consciência fiscal.

A consciência fiscal jamais existirá se não for observado o direito à informação a que o cidadão faz jus relativamente ao quanto paga a título de tributos e, bem assim, sobre o retorno dado à sociedade em termos de obras e serviços úteis à coletividade.

É necessário, pois, que o cidadão-contribuinte seja informado, claramente, a respeito dos valores dos tributos embutidos nos preços das mercadorias que adquire e dos serviços que contrata. Mais do que isso, faz-se necessário despertar no cidadão a importância no que toca à cobrança de tributos, despontando nele cidadania ativa e participativa.

A cidadania é um processo dinâmico, em evolução. E nesse sentido, a ideia é facultar ao cidadão a possibilidade de exigir direitos e cumprir os deveres demandados pela sociedade.

Para tanto, impende destacar a educação do contribuinte, buscando esclarecê-lo acerca desses direitos e deveres, o que, inevitavelmente, o conduzirá a comportamento mais adequado no que se refere às obrigações fiscais.

Há várias noções do termo cidadania, não apenas a jurídica, mas igualmente a social, política, cultural, econômica, e outros aspectos que apenas reforçam a imprecisão de uma definição. Segundo a concepção contemporânea, a participação dos indivíduos na sociedade coteja o tratamento jurídico dispensado a seus integrantes e a ideia de igualdade.

Tratando-se de matéria tributária, interessa a cidadania como participação do indivíduo no Estado, enquanto Fisco, com o objetivo de aprimorar as instituições tributárias. Dito de outro modo, a cidadania, sob o viés tributário, diz respeito à interação dos contribuintes com o Estado Fiscal. 
A tributação é atividade fundamental para a existência do Estado e se faz presente na vida do cidadão. É imperioso lembrar que a própria evolução do Estado prioriza a atuação dos indivíduos, o que determina a noção de cidadania, e desse modo deve ser considerada na seara tributária quanto à postura frente à tributação. $\mathrm{O}$ mais importante é assegurar a participação do cidadão-contribuinte em todos os aspectos da tributação, em apreço a sua cidadania.

O presente estudo, versando o exercício da cidadania fiscal, inicia-se com o exame da origem e evolução histórica da cidadania, para depois tratar da cidadania relativamente à cobrança de tributos, do relevo da noção de consciência fiscal e, por último, dos direitos do consumidor/contribuinte.

\section{ORIGEM E EVOLUÇÃO HISTÓRICA DA CIDADANIA}

Os primórdios da cidadania guardam raízes na Antiguidade Clássica, mais precisamente com a ideia de cidade romana ou na pólis grega. A pólis era formada de homens livres, com ativa participação política em uma democracia direta, e que discutiam fatos vividos por toda a coletividade, gerando direitos e deveres para o cidadão. De fato, os gregos absorviam os ideais de liberdade e valores republicanos, que servem de fundamento para o conceito de cidadania.

Dentre as cidades da Grécia, destaca-se Atenas em função de três qualidades ${ }^{3}$ :

A primeira, residia no fato de que o regime político ateniense atendia aos interesses da maioria dos cidadãos e não os de uma minoria, e, por essa razão, Atenas era uma democracia; a segunda qualidade, encontrava-se na igualdade de todos perante a lei e na adoção do critério do mérito para escolha dos governantes; e, finalmente, Atenas destacava-se porque a origem social humilde não era obstáculo para a ascensão social de qualquer cidadão. Esse célere discurso de Péricles enunciou um conjunto de direitos, que iriam, séculos depois, formar a substância da cidadania moderna: a igualdade de todos perante a lei, a inexistência de desigualdades sociais impeditivas do acesso social e no emprego do mérito como critério de escolha dos governantes.

A democracia em Atenas, reconhecendo a existência de direitos relativos à condição humana, admitia que as instituições governamentais deveriam ser prestadoras de serviços em favor dos governados e não em proveito dos governantes. A história revela que isto ocorreu no século VI a. C., com o surgimento das primeiras instituições democráticas, e

${ }^{3}$ BARRETO, Vicente. O conceito moderno de cidadania. Revista de Direito Administrativo, Rio de Janeiro, v. 192, p. 29-37, fev. 2015. ISSN 2238-5177. Disponível em:

<http://bibliotecadigital.fgv.br/ojs/index.php/rda/article/view/45733/47285>. Acesso em: 15 Jul. 2016 , p. 31. 
continuou no século seguinte com a formação da república romana. Seus ideais eram vinculados ao primado da lei e à participação do cidadão de modo mais eficaz nas funções de governo. Fábio Konder Comparato ${ }^{4}$ bem sintetiza esse momento quando explica que: "por mais de dois séculos (501 a 338 a.C.) o poder dos governantes foi estritamente limitado, não apenas pela soberania das leis, mas também pelo jogo complexo de um conjunto de instituições de cidadania ativa, pelas quais o povo, pela primeira vez na História, governou-se a si mesmo".

Durante os séculos XI e XII, resgata-se o ponto da limitação do poder dos governantes, que é a primeira medida para a verificação da existência de direitos comuns a todos os indivíduos, independentemente de se tratar de clero, nobreza e povo.

Segundo Comparato, a partir do século XI surge a necessidade de "reconstrução da unidade política perdida." 5 Nessa época, a nobreza e o clero lutavam pelo poder, e contra os abusos dessa concentração do poder tiveram início manifestações de rebeldia: "na península ibérica, com a Declaração das Cortes de Leão de 1188, e, sobretudo, na Inglaterra, com a Magna Carta de 1215." 6

Importante registrar que foi com o desenvolvimento da sociedade capitalista, no início do século XV, e com a ascensão da burguesia em guerra com o feudalismo, é que se retoma aos poucos ao exercício da cidadania.

Começou-se a valorizar o trabalho e a aceitá-lo como a medida primeira para a existência da cidadania. E assim, surgiam as cidades, a burguesia ascendia e o comércio crescia. Ao mesmo tempo, viriam novas descobertas nas ciências.

É fato que todas essas mudanças se encaixam com o pensamento firmado bem depois, sobre a possibilidade de todos serem iguais, embora essa igualdade fosse considerada apenas perante a lei.

Bastante significativo que à época, o Habeas Corpus e o Bill of Rights, de 1679, não favoreciam a todos sem distinção, somente ao clero e à nobreza, não obstante ter sido uma forte referência ao estatuto das liberdades civis e políticas, e dele tenha se utilizado também a burguesia rica. ${ }^{7}$

Alice Mouzinho destaca que "na filosofia de Kant, a pessoa é colocada como sujeito de direitos universais, anteriores e superiores a toda ordenação estatal. Da relação entre

${ }^{4}$ COMPARATO, Fábio Konder. A afirmação histórica dos direitos humanos, p. 43.

${ }^{5}$ Idem, ibidem, 45-46.

${ }^{6}$ Idem, ibidem, p. 46.

${ }^{7}$ Idem, ibidem, p.49. 
indivíduos e estados nacionais advém o Estado de Direito, com base na lei. A estruturação da cidadania se dá através da lei das pressões sociais, e está sempre em processo". ${ }^{8}$

Fábio Konder Comparato cita a Declaração de Virgínia ${ }^{9}$, de 16.06.1776 e que para ele "constitui o registro de nascimento dos direitos humanos na História". Eis o que diz o artigo I:

Todos os seres humanos são, pela sua natureza, igualmente livres e independentes, e possuem certos direitos inatos, dos quais, ao entrarem no estado de sociedade, não podem, por nenhum tipo de pacto, privar ou despojar sua posteridade; nomeadamente, a fruição da vida e da liberdade, com os meios de adquirir e possuir a propriedade de bens, bem como de procurar e obter a felicidade e a segurança.

Em 1789, veio a Revolução Francesa, e a burguesia condicionava os direitos humanos apenas aos que detinham propriedades. Para os educados e proprietários, existia o voto censitário, tornando, assim, o cidadão ativo ou passivo ${ }^{10}$.

Com a democracia moderna constituída na América do Norte e na França, a burguesia procurou preservar-se do clero e da nobreza, ficando o governo responsável ante a classe burguesa, mas ao mesmo tempo restrito em seus poderes.

T. H. Marshall ${ }^{11}$ defendeu a cidadania como status. Para o citado autor, três elementos integram a cidadania: o elemento civil, relativo aos direitos necessários à liberdade individual; o elemento político, concernente ao direito de participar no exercício do poder político; e o elemento social, referente a tudo o que vai desde o direito a um mínimo de bemestar econômico e segurança ao direito de participar, por completo, na herança social e levar a vida de um ser civilizado de acordo com os padrões que prevalecem na sociedade. E o período de formação de cada um desses elementos é correspondente a um século diferente - os direitos civis, ao século XVIII; os políticos, ao século XIX; os sociais, ao século XX.

Expõe Walter Costa Porto $^{12}$, com a propriedade que lhe é peculiar, que a maior crítica a Marshall vem daqueles que julgam não se possa naquele século XVIII separar direitos civis dos políticos; o conceito de direitos humanos teria se expressado, ali, "em termos inteiramente políticos".

\footnotetext{
${ }^{8}$ BARBOSA, Alice Mouzinho. Cidadania fiscal, p. 34.

${ }^{9}$ Op, cit, p. 50.

${ }^{10}$ Op. cit., p. $29-37$.

${ }^{11}$ MARSHALL, T. H. Cidadania e Classe Social,vol. I, p. 9.

${ }^{12}$ Apresentação, in MARSHALL, T. H. Ibidem, p. 7.
} 
Norberto Bobbio ${ }^{13}$ emprega uma análise histórica, defendendo que os direitos naturais são direitos históricos. O referido autor os distingueem quatro gerações, que servem como marco do progresso histórico. Eis a distinção: 1. Direitos de Liberdade; 2. Direitos Sociais; 3. Direitos Heterogêneos da categoria ecológicos; 4. Direitos referentes à pesquisa biológica.

Com o fim das duas grandes guerras, surgiram novos direitos fundamentais, dentre eles os direitos econômicos e sociais. Na verdade, trata-se de um reflexo do sofrimento deixado pela guerra, da premência de reconstrução da sociedade europeia e também do reconhecimento do valor da dignidade humana.

No que se refere à internacionalização dos direitos humanos, pode-se dizer que ela confere ao indivíduo status de sujeito de direito internacional. Segundo Piovesan ${ }^{14}$, "aos poucos, emerge a ideia de que o indivíduo é não apenas objeto, mas também sujeito de Direito Internacional ". É fato que a legitimação desses direitos evoca uma responsabilidade do Estado violador e confere ao cidadão uma função de sujeito de direito internacional.

A partir daí, são assinados pactos internacionais sobre direitos civis e políticos e sobre direitos econômicos, sociais e culturais, surgindo um novo momento da história, a que Konder Comparato ${ }^{15}$ intitula como "a era da cidadania mundial".

É possível dizer que o conceito de cidadania tem conexão com o de direitos humanos. Nessa perspectiva, Ricardo Lobo Torres ${ }^{16}$ justifica a construção de uma cidadania jurídica ou legal, vez que esse conceito não está apenas limitado à ideia de cidade ou Estado nacional, mas se funda em espaço internacional e supranacional.

Prossegue, primorosamente, Torres: "o conceito hodierno de cidadania, em suma, compreende os direitos fundamentais, os políticos, os sociais e econômicos e os difusos, em constante tensão com as ideias de liberdade, de justiça política, social e econômica, de igualdade de chances e de resultados, e de solidariedade, a que se vinculam.

O modelo atual de cidadania deve ser analisado sob novo enfoque, afinal, o mundo moderno, com suas redes de informação e troca de dados constitui uma ameaça à concepção de cidadania plena. J. J. Calmon de Passos ${ }^{17}$ bem sintetiza esse momento quando explica que:

\footnotetext{
${ }^{13}$ BOBBIO, Norberto. A era dos direitos, p. 2, 5 e 6.

${ }^{14}$ PIOVESAN, Flávia. Direitos humanos e o direito constitucional, p. 118.

${ }^{15}$ COMPARATO, Fábio Konder, op. cit., p. 69.

${ }^{16}$ TORRES, Ricardo Lobo. Teoria dos direitos fundamentais, p. 251 e 258.

${ }^{17}$ PASSOS, J. J. Calmon de. Cidadania Tutelada. Revista Diálogo Jurídico, Salvador, CAJ - Centro de Atualização Jurídica, v. I, n. 7, out. 2001. Disponível em: http://www.direitopublico.com.br. Acesso em: 4 Jul. 2016.
} 
Cidadania, portanto, engloba mais que direitos humanos, porque além de incluir os direitos que a todos são atribuídos, em virtude de sua condição humana, abrange, ainda, os direitos políticos. Correto, por conseguinte, falarse numa dimensão política, numa dimensão civil e numa dimensão social da cidadania. Ser cidadão implica na efetiva atribuição de direitos nas três esferas mencionadas, porque careceria de sentido participar do governo sem condições de fazer valer a própria autonomia, bem como sem dispor de instrumentos asseguradores das prestações devidas, pelo Estado, em nome da igualdade de todos.

No que se refere à evolução histórica da cidadania nacional, José Murilo de Carvalho $^{18}$, ao cotejar a do Brasil com a da Inglaterra, segundo o modelo de Marshall, reconhece caminhos opostos entre esses países. Houve duas diferenças significativas: destaque do direito social em relação aos outros direitos e mudança na ordem de aquisição de direitos. Entre nós, inclusive, o social precedeu os outros.

Durante o período de colonização, a visão de cidadania no Brasil, até a Independência, era de sujeição ao rei ou dele sermos considerados súditos. Do descobrimento do Brasil até a abolição da escravatura, é possível afirmar a existência de uma sociedade escravista, em que os valores de igualdade, bem como a noção de direitos civis, políticos ou sociais foram simplesmente desvirtuados. Não é demais lembrar a existência dos grandes latifúndios e do poder privado dos senhores, que foi outro legado marcante dessa época.

Em relação aos direitos políticos, a cena eleitoral do Império excluía largos contingentes populacionais. Segundo Walter Costa Porto ${ }^{19}$, “a primeira exclusão era a do agrupamento feminino: os cidadãos, a quem a Constituição de 1824 concedia o sufrágio, não envolvia as mulheres; a segunda, a exclusão pela renda, que valeu, também, por todo o período monárquico e que, a partir de 1881, foi agravada pela Lei Saraiva com o aumento das exigências para sua comprovação". Menciona, ainda, o autor que "a Primeira República reforçou esse quadro, mantendo a exclusão das mulheres, afastando os analfabetos - aos quais o império permitira o voto". Na verdade, um movimento na contramão do que ocorria nos países europeus, onde os direitos políticos estavam cada vez mais alargados.

Pode-se afirmar que o coronelismo de nossas oligarquias dominava o poder público, fazendo com que seus privilégios fossem preservados. Ademais, o Estado brasileiro estava estruturado numa política de dominação.

\footnotetext{
${ }^{18}$ CARVALHO, José Murilo de. Cidadania no Brasil: o longo caminho, p.11-12.

${ }^{19}$ Op. cit., p. 8 .
} 
Foi com a República que surgiu o primeiro Código Civil, publicado em 1916, tendo sido um dos instrumentos para o fortalecimento do Estado de Direito e da democracia. Os direitos sociais avançaram depois de 1930, alcançando os trabalhadores urbanos e depois os rurais. Para Alice Mouzinho 20 "são os direitos civis e políticos os mais frequentemente desrespeitados nos regimes discricionários, principalmente porque os direitos políticos, com a exigência de participação popular, constituem ameaça".

A Constituição Federal de 1988 foi um marco histórico para o país, notadamente com vistas à redemocratização, e foi também um marco em relação à cidadania e aos direitos humanos, pois assegurou conquistas significativas nessas áreas. Referido documento constitucional foi apelidado de "Constituição Cidadã" em decorrência da grande quantidade de dispositivos voltadas para a defesa e a garantia de direitos sociais.

Em seu art. $1^{\circ}$, a CRFB/88 dispôs a respeito dos direitos políticos da cidadania, exercidos através do voto, in verbis:

Art. $1^{\circ}$. A República Federativa do Brasil, formada pela união indissolúvel dos Estados e Municípios e do Distrito Federal, constitui-se em Estado Democrático de Direitos e tem como fundamentos: I - a soberania; II - a cidadania; III - a dignidade da pessoa humana; IV - os valores sociais do trabalho e da livre iniciativa; V - o pluralismo político.

E no parágrafo único do artigo acima, trata da soberania popular - "Todo o poder emana do povo, que o exerce por meio de representantes eleitos ou diretamente, nos termos desta Constituição”. Está declarado aí o princípio da soberania popular, abordando a participação política, tanto pelo exercício direto quanto indireto.

Com efeito, é na democracia representativa que se desenvolvem a cidadania, bem como a representatividade que fortalece o regime democrático. Precisas as lições de José Afonso da Silva ${ }^{21}$, ao afirmar que

A democracia, em verdade, repousa sobre dois princípios fundamentais ou primários, que lhe dão a essência conceitual: a) o da soberania popular, segundo o qual o povo é a única fonte do poder, que se exprime pela regra de que todo o poder emana do povo; b) a participação, direta ou indireta, do povo no poder, para que este seja efetiva expressão da vontade popular; nos casos em que a participação é indireta, surge um princípio derivado ou secundário: o da representação.

Extraem-se do exame da CRFB/88 dispositivos que consagram a participação do povo no poder, tais como o inciso XXXIII do artigo $5^{\circ}$ : “Todos têm direito a receber dos órgãos

\footnotetext{
${ }^{20}$ BARBOSA, Alice Mouzinho, op. cit., p. 44.

${ }^{21}$ SILVA, José Afonso da. Curso de direito constitucional positivo, p. 131.
} 
públicos informações de seu interesse particular, ou de interesse coletivo ou geral, que serão prestadasno prazo da lei, sob pena de responsabilidade, ressalvadas aquelas cujo sigilo seja imprescindível à segurança da sociedade e do Estado".

Entretanto, é importante destacar que a referida norma deve estar harmonizada com o inciso LX do citado artigo 50: "A lei só poderá restringir a publicidade dos atos processuais quando a defesa da intimidade ou o interesse social o exigirem".

Não é necessário grande esforço de raciocínio para se concluir que o direito à informação é expressão inerente ao direito à participação, no sentido de se poder participar do conhecimento. Assim sendo, é coerente afirmar que democracia e participação caminham juntas no Estado democrático de direito.

Nesse sentido, "a cidadania interessada, ou melhor, motivada, consente e legitima pelo consenso a cobrança de um imposto ou outra qualquer prática administrativa." ${ }^{22}$. Sem dúvida, é mais razoável alcançar o cumprimento de uma decisão inicialmente defendida e aceita, que o oposto.

Não se pode olvidar que o direito à informação adequada deve ser um dos sustentáculos do direito do contribuinte, assim como o é no direito do consumidor. O contribuinte é o titular do direito à informação e assim sendo, a dignidade humana ficará comprometida, caso haja desinformação de sua parte.

\section{A COBRANÇA DE TRIBUTOS E A CIDADANIA}

$\mathrm{Na}$ antiguidade, o Estado valeu-se de diversos mecanismos para suportar as despesas necessárias ao alcance de seus objetivos. E nesse sentido, constituíram os tributos meio de entrada de recursos aos cofres públicos. Mas o acréscimo dos tributos ocorreu de maneira demasiada, a ponto de provocar movimentos na sociedade em desfavor da tributação não consentida.

Importante destacar a Magna Carta, de 21.06.1215, que nesse cenário foi bastante relevante. Segundo Mouzinho ${ }^{23}$, a referida Carta "foi outorgada na Inglaterra, como resultado de um acordo entre barões revoltados, aliados aos burgueses londrinos contra João Sem-Terra. Neste documento está a garantia de direitos como a liberdade de ir e vir, de propriedade privada e também a regra non taxation without representation". Essa última regra estabelece o consenso

\footnotetext{
${ }^{22}$ BARBOSA, Alice Mouzinho. Op. cit., p. 52.

${ }^{23}$ Idem, ibidem, p. 58.
} 
de que apenas paga imposto quem está representado, melhor dizendo, quem indiretamente consentiu, por meio do voto, na tributação.

Comparato $^{24}$ salienta que a Magna Carta foi bastante significativa, uma vez que deixou subentendido que o rei estaria vinculado às próprias leis que editara. Inclusive, os avanços reconhecidos com a citada Carta terminaram fortalecidos em outros importantes documentos, como na Petition of Rights, de 07.06.1628, que declara obediência ao princípio do consentimento na tributação.

A Declaração de Direitos da Virgínia, de 12.1.1776, trouxe de forma expressa a exigência de consentimento para a tributação, por intermédio de representantes eleitos: “... e não podem ser tributados ou expropriados por utilidade pública, sem o seu consentimento ou o de seus representantes eleitos, nem podem ser submetidos a nenhuma lei, à qual não tenham dado, da mesma forma, o seu consentimento para o bem público" ${ }^{25}$. Para José Afonso da Silva ${ }^{26}$, esta foi "a primeira declaração de direitos fundamentais, em sentido moderno".

Na Declaração de Independência dos Estados Unidos, de 4.7.1776 registrou-se o inconformismo quanto à imposição de tributos não assentidos: “... Para impor tributos sem o nosso consentimento". ${ }^{27}$

A Declaração dos Direitos do Homem e do Cidadão - Declaração Francesa de 1789, já tratava do princípio da capacidade contributiva, em seu art. 14: “Todos os cidadãos têm o direito de verificar, pessoalmente ou por meio de representantes, a necessidade da contribuição pública, bem como de consenti-la livremente, de fiscalizar o seu emprego e de determinar-lhe a alíquota, a base de cálculo, a cobrança e a duração". ${ }^{28}$

Ademais, do rol de direitos do homem e do cidadão (Declaração Francesa de 1789) extrai-se a possibilidade de o cidadão atuar nas decisões de governo, quando escolhe seus representantes, e a partir daí, anuir com a cobrança de impostos, fiscalizar os gastos públicos, dentre outros direitos. ${ }^{29}$ Eis os artigos:

Art. 6. A lei é expressão da vontade geral. Todos os cidadãos têm o direito de concorrer pessoalmente, ou por meio de representantes, à sua formação. Ela deve ser a mesma para todos, quer proteja, quer puna. Todos os cidadãos, sendo iguais aos seus olhos, são igualmente admissíveis a todas as dignidades,

\footnotetext{
${ }^{24}$ COMPARATO, Fábio Konder. Op. cit., p.79-80.

${ }^{25}$ COMPARATO, Fábio Konder. Op. cit., p.119.

${ }^{26}$ SILVA, José Afonso da. Op. cit., p. 153.

${ }^{27}$ COMPARATO, Fábio Konder. Op. cit., p.110.

${ }^{28}$ Idem, ibidem, p.159.

${ }^{29}$ Idem, ibidem, p. 159.
} 
cargos e empregos públicos, segundo a sua capacidade e sem outra distinção a não ser a de suas virtudes e seus talentos.

Art. 12. A garantia dos direitos do homem e do cidadão carece de uma força pública; esta força é, portanto, instituída em proveito de todos, e não para utilidade particular daqueles a quem é confiada.

Art. 13. Para a manutenção da força pública e para as despesas da administração, é indispensável uma contribuição comum; ela deve ser igualmente repartida entre todos os cidadãos, na medida de seus recursos.

Art. 14. Todos os cidadãos têm o direito de verificar, pessoalmente ou por meio de representantes, a necessidade da contribuição pública, bem como de consenti-la livremente, de fiscalizar o seu emprego e de determinar-lhe a alíquota, a base de cálculo, a cobrança e a duração.

Com efeito, os artigos 12 e 14 expressam o princípio no taxation without representation, ou seja, não haverá tributação sem que os contribuintes consintam por meio de seus representantes.

Alice Mouzinho ${ }^{30}$ leciona que a Constituição de 1824 “declarou direitos e garantias que normatizavam a tributação: ninguém será isento de contribuir para as despesas do Estado em proporção dos seus haveres (art. 179, item 15); ficam abolidos todos os privilégios que não forem essencial e inteiramente ligados aos cargos por utilidade pública (art. 179, item 16)". Para a citada autora, "estava aí a matriz histórica do princípio da personalização do tributo".

No cenário brasileiro, importante registrar a Inconfidência Mineira, que foi uma manifestação motivada, sobretudo, pela sangria econômica provocada por Portugal devido ao aumento dos impostos.

Após o regime imperial, veio a fase republicana, com o Decreto n. 1, de 15.11.1889, sendo posteriormente promulgada a Constituição da República dos Estados Unidos do Brasil, no dia 24.2.1891. As demais cartas constitucionais da República trataram da matéria tributária de modo sistemático.

Nesse contexto, necessário ressaltar a questão da eficácia das normas de Declaração de Direitos, no sentido de que não basta a simples inscrição dos direitos fundamentais, mas o alcance efetivo desses direitos.

Alberto Nogueira ${ }^{31}$ entende que "o primeiro caminho para a reconstrução dos Direitos Humanos da Tributação é o da efetiva, direta e ativa participação de todos os segmentos da sociedade na elaboração, fiscalização e controle das regras tributárias", abolindo os excessos e injustiça da carga tributária. No contraponto, não há espaço para a sonegação de impostos,

\footnotetext{
${ }^{30}$ BARBOSA, Alice Mouzinho. Op. cit., p. 63.

${ }^{31}$ NOGUEIRA, Alberto. A reconstrução dos direitos humanos da tributação, p. 411-416.
} 
que beneficia seu autor, mas castiga os contribuintes e o mais lastimável, desonra o serviço público. Prossegue o citado autor, afirmando que "o segundo caminho passa pelo Poder Judiciário, uma das vias mais importantes para o saneamento do sistema saturado de tributação que hoje nos aflige" e no terceiro caminho, surge a Constituição, com suas ramificações, tanto no âmbito jurídico, quanto econômico e político.

É possível afirmar que o exercício da cidadania fiscal ocorrerá no instante em que houver sujeição do Estado ao direito, bem como o respeito à cidadania ativa, além de o contribuinte poder exercer seu papel na atividade tributária.

\section{CONSCIÊNCIA FISCAL}

Impende inicialmente destacar elucidativas palavras de Ricardo Lobo Torres a propósito do dever de pagar tributos, para quem ${ }^{32}$

...o dever de pagar tributos surge com a própria noção moderna de cidadania e é coexistente à ideia de Estado de Direito. Tributo é dever fundamental estabelecido pela Constituição no espaço aberto pela reserva da liberdade e pela declaração dos direitos fundamentais. Transcende o conceito de mera obrigação prevista em lei, posto que assume dimensão constitucional.

Aliomar Baleeiro ${ }^{33}$ destaca a importância da consciência fiscal, expressão utilizada pelos ingleses que a identificam como tax consciousness. Referido termo traduz o estado de espírito de quem conhece o valor de quanto paga e o seu esforço para manutenção dos serviços públicos. Em outras palavras, é a consciência que a carga tributária não pesa apenas nos ombros de quem tem o dever legal de efetuar o pagamento de tributos, mas também sobre os ombros de quem, como comprador de mercadorias ou tomador de serviços, paga um preço no qual estão embutidos os tributos.

É bem verdade que numa sociedade democrática, essa consciência que se espera do cidadão, no tocante à distribuição das despesas imprescindíveis ao regular funcionamento da máquina estatal, é considerada essencial. Ocorre que, geralmente, não é grande a parcela da população que tem compreensão a esse respeito. A maioria, pelo contrário, supõe que os tributos incidem sobre os grandes contribuintes, ou seja, os empresários e prestadores de serviços e chega, inclusive, a desconhecer o tributo que é pago, embutido no preço das mercadorias e na aquisição de serviços.

\footnotetext{
${ }^{32}$ TORRES, Ricardo Lobo. Op. cit., p. 318.

${ }^{33}$ BALEEIRO, Aliomar. Uma introdução à ciência das finanças, p. 196.
} 
Relativamente aos impostos indiretos, os contribuintes de direito - industriais, banqueiros, comerciantes - transferem o encargo tributário aos consumidores finais das mercadorias ou serviços e, desse modo, acabam se desonerando do valor do tributo. Trata-se do fenômeno da repercussão ou translação do tributo.

Embora seja improvável que se conheçam todos os efeitos econômicos da tributação, isso não implica dizer que se descuide da importância da consciência fiscal. Na verdade, ela gera maior participação do cidadão contribuinte em seu meio social, buscando mais ativamente melhorias para a qualidade de vida em comunidade.

Segundo Baleeiro ${ }^{34}$, "os impostos que mais ferem a sensibilidade dos contribuintes e despertam, no espírito deles, a consciência fiscal são exatamente os mais justos e de mais benéficos efeitos econômicos: os diretos e pessoais, como o sobre a renda, sobre a herança, sobre a propriedade, elementos seguros de capacidade contributiva".

Em oposição, o citado autor ressalta a anestesia fiscal, que é característica dos impostos de consumo e outros indiretos e reais. Ele afirma que "esses impostos são regressivos ou inversamente progressivos, isto é, retiram aos pobres maior percentagem de recursos do que aos ricos, já que os artigos de alimentação e vestuário absorvem a quase totalidade dos salários e apenas pequena parte dos altos rendimentos das classes abastadas". ${ }^{35}$

Nesse contexto, convém lembrar o que estabelece o artigo $150, \S 5^{\circ}$, da Constituição Federal, da seguinte forma: “A lei determinará medidas para que os consumidores sejam esclarecidos acerca dos impostos que incidam sobre mercadorias e serviços."

O referido dispositivo constitucionaliza a transparência da carga tributária incidente principalmente sobre bens e serviços - tributação indireta. E quando se analisa o fenômeno da repercussão financeira, verifica-se que tais impostos são suportados pelo consumidor final dos bens e serviços por eles onerados. O que acontece rotineiramente é o fato de a grande maioria dos cidadãos nem perceber esse ônus, mas baseado neste artigo constitucional, o consumidor, contribuinte de fato do imposto, precisará ser explicado a respeito da carga tributária integrante do preço final dos produtos e serviços que adquira.

A fim de cumprir a determinação do citado $\S 5^{\circ}$ do artigo 150 da Constituição Federal, foi editada a Lei $\mathrm{n}^{\mathrm{o}} 12.741$, de 08 de dezembro de 2012, regulamentada pelo Decreto $n^{\circ} 8.264 / 14$, que obriga as empresas a divulgarem, na documentação fisscal, o valor aproximado dos tributos federais, estaduais e municipais cuja incidência influi na formação de seus preços

\footnotetext{
${ }^{34}$ Idem, ibidem, p. 236.

${ }^{35}$ Idem, ibidem, p. 236.
} 
de venda. Para tanto, serão considerados os seguintes tributos: ICMS, ISS, IPI, IOF, PIS/PASEP, COFINS e CIDE.

Ainda assim, tem-se que reconhecer que não é pequeno o número de contribuintes desinformados, vivendo em um estado de anestesia fiscal, crendo que não estão pagando tributos quando na verdade eles incidem em praticamente tudo: consumo, prestação de serviços, renda etc.

É evidente que em um ideal de isonomia deveria dar-se ênfase aos tributos diretos (imposto de renda, por exemplo), utilizando-se da técnica de progressividade. Nesta sistemática, tributam-se desigualmente os que se encontram em situação econômica distinta, segundo a premissa de que deve pagar mais quem pode pagar mais.

Verifica-se, pois, que o sistema tributário deve ser o mais justo possível, gravando os contribuintes de acordo com a sua capacidade contributiva, e, além disso, deve dar-se ênfase à transparência fiscal. Sabendo os contribuintes, pelo menos aproximadamente, o valor dos tributos que pagam, passam a ter maior consciência fiscal, que poderá conduzi-los a desejar participar mais ativamente das decisões governamentais, exercendo a cidadania fiscal.

\section{O CIDADÃO COMO CONSUMIDOR/CONTRIBUINTE}

Conforme já dito, o resgate da cidadania no Brasil teve o seu momento culminante no artigo $1^{\circ}$, inciso II, da Constituição Federal de 1988, que a incluiu entre os fundamentos do Estado Democrático de Direito.

Para Ricardo Lobo Torres ${ }^{36}$, “o estudo jurídico da cidadania deve considerá-la a partir das diversas dimensões em que aparece". São elas: dimensão temporal, dimensão espacial, dimensão bilateral e a dimensão processual. “A cidadania, conseguintemente, é multidimensional", segundo Torres ${ }^{37}$.

Com efeito, a cidadania abrange os direitos humanos, os políticos, os sociais e econômicos, os coletivos e difusos, bem como os deveres decorrentes desses direitos. Porém, é possível afirmar que a relação entre direitos e deveres da cidadania é assimétrica.

Conforme Ricardo Lobo Torres ${ }^{38}$, “ao direito público subjetivo de cada cidadão nem sempre corresponde a mesma carga de deveres, eis que alguns deveres se impõem ao grupo

\footnotetext{
${ }^{36}$ TORRES, Ricardo Lobo. Op. cit., p. 256.

${ }^{37}$ Idem, ibidem, p. 256.

${ }^{38}$ Idem, ibidem, p. 317.
} 
social de que participa o indivíduo". Por exemplo, o dever de pagar tributo não está diretamente relacionado com o exercício dos direitos fundamentais, ainda que indiretamente mantenham ligação. Continua o autor: "Tal assimetria entre direitos e deveres decorresobretudo da ideia de solidariedade que informa a cidadania. Os direitos fundamentais e os sociais são usufruídos solidariamente porque sustentados por deveres de solidariedade".

É fato que o cidadão contribuinte, que busca do Estado o reconhecimento de um direito, quer seja de modo formal ou informal, resguarda seus interesses e constrói uma identidade social de um pagador de impostos. Segundo Alice Mouzinho ${ }^{39}$, "a identidade social e nacional construída pelos cidadãos, muitas vezes informalmente, é que dá o sentido impulsionador e valorativo a determinadas práticas que se tornam relevantes para o desenvolvimento e conquista de novos direitos pela sociedade, e que constituirão a evolução da cidadania".

Demais disso, o poder do cidadão consumidor/contribuinte só se afirma quando é reconhecido coletivamente e, sobretudo, quando é reconhecido pelo Estado. Para tanto, Bobbio $^{40}$ afirma que "o problema grave do nosso tempo, com relação aos direitos do homem, não está em fundamentá-los e sim, em protegê-los. O problema não é filosófico, segundo o autor, não deve envolver discussões sobre a natureza e fundamentos dos direitos, mas é problema jurídico e, num sentido mais amplo, político".

A intenção do cidadão como consumidor/contribuinte nada mais é que ter resguardados os direitos que lhe são assegurados na Constituição Federal de 1988. O referido documento, sem dúvida, imprimiu, segundo Mouzinho ${ }^{41}$, “caráter de irreversibilidade e de inesgotabilidade aos direitos e garantias do cidadão e à declaração dos direitos dos contribuintes, dentre eles os princípios da legalidade, irretroatividade, anterioridade, vedação ao confisco, tributação conforme a capacidade contributiva, inseridos no art. 150 e que se juntam aos do art. $5^{\circ} \%$.

O contribuinte é reconhecidamente vulnerável e hipossuficiente. E assim sendo, a alternativa do legislador foi a de protegê-lo, estabelecendo aos fornecedores de produtos e aos prestadores de serviços a necessidade de atuarem de modo eficaz, segura, mantendo o contribuinte inteirado sobre os serviços fornecidos, produtos e tributos que são impostos. A propósito, eis o que afirma o $\S 5^{\circ}$ do artigo 150 da CRFB/88, já citado em outro momento:

\footnotetext{
${ }^{39}$ BARBOSA, Alice Mouzinho. Op. cit., p. 90.

${ }^{40}$ BOBBIO, Norberto. Op. cit, p. 30.

${ }^{41}$ BARBOSA, Alice Mouzinho. Op. cit., p. 93.
} 
Art. 150. Sem prejuízo de outras garantias asseguradas ao contribuinte, é vedado à União, aos Estados, ao Distrito Federal e aos Municípios:

$\S 5^{\circ}$ - A lei determinará medidas para que os consumidores sejam esclarecidos acerca dos impostos que incidam sobre mercadorias e serviços.

Trata-se de norma constitucional não auto-executável, isto é, constitui norma incompleta, carecedora de lei que a complemente. Aliás, raros assuntos do direito constitucional têm importância tão fundamental quanto o que se refere à natureza e eficácia das normas constitucionais. Inclusive, Pontes de Miranda não ignorou o assunto, tanto que escreveu: “... Quando, porém, precisam as regras jurídicas de regulamentação, porque, sem a criação de novas regras jurídicas, que as completem ou suplementem, não poderiam incidir e, pois, ser aplicadas, dizem-se não bastante em si”. ${ }^{42}$ A norma é considerada de "eficácia limitada ou reduzida" 43 , ou seja, depende de norma ulterior que lhe dê aplicabilidade.

Assim é que foi editada a Lei $\mathrm{n}^{\circ} 12.741 / 12$, norteada pelo disposto no $\S 5^{\circ}$ do artigo 150 da CRFB/88, que, na verdade, trata de assunto correlato ao Direito do Consumidor. Com efeito, tal Lei implementa alterações no Código de Defesa do Consumidor (Lei nº 8.078/90) e, ademais, determina a aplicação das penalidades previstas nesse Código às pessoas que descumprirem as suas disposições.

Anuncia Alice Mouzinho ${ }^{44}$ que "o conceito de consumidor no Mercosul é o de toda pessoa física ou jurídica que adquire ou utiliza produtos ou serviços como destinatário final em uma relação de consumo ou em função dela”. Pode-se constatar que essa concepção não está longe do que se entende por quem seja a parte mais vulnerável numa relação de consumo, até porque se trata da mesma pessoa, exercendo papel de consumidor e também de contribuinte.

Ressalte-se ainda que alguns autores defendem a criação de estatuto do contribuinte como instrumento no ordenamento jurídico que possa assegurar os direitos conquistados pelo cidadão. Segundo Mouzinho ${ }^{45}$, "a expressão Estatuto do Contribuinte significa um conjunto de normas que venham a regular a relação entre o contribuinte e o ente tributante, o fissco", tendo vinculação com a proteção dos contribuintes.

O contribuinte tem direito à informação sobre os impostos pagos na aquisição de mercadorias ou na prestação de serviços. Ademais, é preciso haja transparência, por parte da

\footnotetext{
${ }^{42}$ Bonavides, Paulo. Curso de direito constitucional, p. 242,

${ }^{43}$ Idem, ibidem, p. 244.

${ }^{44}$ BARBOSA, Alice Mouzinho. Op. cit., p. 97.

${ }^{45}$ Idem, ibidem, p. 101.
} 
Administração Pública, no trato com o dinheiro público, além de uma legislação tributária mais objetiva, didática, desburocratizada e coerente na aplicação dos tributos arrecadados.

No Brasil, um Projeto do Código de Defesa do Contribuinte, Projeto de Lei Complementar n646/1999, tramitou no Senado Federal, mas foi arquivado em 10/01/2011. O fundamento deste código era o de fortalecer a cidadania do contribuinte e, consequentemente, pôr o Brasil em sintonia com a melhor legislação internacional sobre o tema.

\section{CONCLUSÃO}

Quando se fala em cidadania fiscal, quer-se referir não é apenas ao comerciante, ao empresário, ao alfabetizado. Pelo contrário, o intuito é alcançar, com essa cidadania, a todos os contribuintes, incluindo os mais carentes, por meio de ação positiva do Estado.

Cabe ressaltar que, além do princípio da capacidade contributiva, o que se busca é a não-tributação do que se entende como o mínimo existencial e também o desenvolvimento da justiça, no sentido de possibilitar o exercício da cidadania fiscal.

Importante, ainda, destacar o direito à informação e que se viabiliza principalmente no aperfeiçoamento da legislação. O sujeito passivo da relação jurídico-tributária não deve ser a parte menos favorecida, despersonalizada, mas sim sujeito de direitos e obrigações tributárias. Deve ele, como cidadão, ser reconhecido e, sobretudo, dispor de meios de defesa em seu benefício que o identifiquem como pessoa merecedora do respeito que o Direito pode e deve assegurar. E não é demais lembrar que a cidadania exige comportamento respeitoso por parte da Administração.

Abrange a cidadania fiscal uma contenção das renúncias fiscais, pois com as políticas de incentivos fiscais e a concessão de subsídios e privilégios às empresas, acabam penalizando o cidadão-contribuinte, que sofre o aumento da carga tributária e no Brasil, é sabido que esta carga supera a média da maioria países do mundo. Ademais, o cidadão não tem o retorno adequado de serviços públicos, como saúde, educação, segurança, lazer, infraestrutura etc.

Urge uma conscientização por parte do cidadão, eis que a sua falta, assim como a de acesso às informações, está relacionada à ineficiência do Estado, no sentido de compelir a violação dos direitos humanos e de assegurar os direitos sociais e políticos postos na Constituição Federal de 1988. 
Os direitos humanos, assim entendidos os direitos civis, políticos e sociais de todo cidadão, devem caminhar juntos, de forma conjugada, com o propósito de se atingir a cidadania fiscal e participativa. Faz-se necessário, também, que o Estado, como um todo, assegure os direitos e desenvolva políticas que abracem os excluídos.

\section{REFERÊNCIAS}

BALEEIRO, Aliomar. Uma introdução à ciência das finanças. 17. ed. rev. e atual. Rio de Janeiro: Forense, 2010.

BARBOSA, Alice Mouzinho. Cidadania fiscal. Curitiba: Juruá, 2005.

BARRETO, Vicente. O conceito moderno de cidadania. Revista de Direito Administrativo, Rio de Janeiro, v. 192, p. 29-37, fev. 2015. ISSN 2238-5177. Disponível em: $\langle$ http://bibliotecadigital.fgv.br/ojs/index.php/rda/article/view/45733/47285 >. Acesso em: $11 \mathrm{Jul}$. 2016.

BRASIL, Constituição da República Federativa do Brasil, promulgada em 05 de $\begin{array}{lllll}\text { outubro de } & 1988 . & \text { Disponível em }\end{array}$ http://www.planalto.gov.br/ccivil 03/Constituicao/Constituicao.htm. Acesso em:24 de Jun. de 2016.

BOBBIO, Norberto. A era dos direitos. Trad. Carlos Nelson Coutilho. Rio de Janeiro: Campos, 1992.

BONAVIDES, Paulo. Curso de direito constitucional. 13. ed. rev. e atual. São Paulo: Malheiros Editores, 2003.

CARVALHO, José Murilo de. Cidadania no Brasil: o longo caminho. 16. ed. Rio de Janeiro: Civilização Brasileira, 2013.

COMPARATO, Fábio Konder. A afirmação histórica dos direitos humanos. 5. ed. rev. e atual. São Paulo: Saraiva, 2007. 
MARSHALL, T. H. Cidadania e Classe Social. [ed. atual. e rev. por EaD/CEE/MCT] 2. ed. Brasília: Senado Federal, Centro de Estudos Estratégicos, Ministério da Ciência e Tecnologia, 2002.

NOGUEIRA, Alberto. A reconstrução dos direitos humanos da tributação. Rio de Janeiro: Renovar, 1997.

PASSOS, J. J. Calmon de. Cidadania Tutelada. Revista Diálogo Jurídico, Salvador, CAJ - Centro de Atualização Jurídica, v. I, n. 7, out. 2001. Disponível em: http://www.direitopublico.com.br. Acesso em: 4 Jul. 2016.

PIOVESAN, Flávia. Direitos humanos e o direito constitucional. 10. ed. rev. e ampl. São Paulo: Saraiva, 2009.

PORTO, José da Costa. A Cidadania no Brasil - o voto/ Costa Porto, J. ... [et all]; [ed. atual. e rev. por EaD/CEE/MCT] 2. ed. Brasília: Senado Federal, Centro de Estudos Estratégicos, Ministério da Ciência e Tecnologia, 2002.

SILVA, José Afonso da. Curso de direito constitucional positivo. 32. ed. rev. e ampl. São Paulo: Malheiros Editores.

TORRES, Ricardo Lobo. Teoria dos direitos fundamentais. 2. ed. Rio de Janeiro: Renovar, 2001. 